УДК 615.451.2:615.281.9:001.891

DOI https://doi.org/10.11603/2312-0967.2021.1.11939

\title{
ДОСЛІДЖЕННЯ АНТИБАКТЕРІАЛЬНИХ ВЛАСТИВОСТЕЙ ЕКСТЕМПОРАЛЬНОЇ СУСПЕНЗІЇ З ВІСМУТУ НІТРАТОМ ОСНОВНИМ
}

\author{
Г. М. Мельник' , Т. Г. Ярних ${ }^{1}$, Г. Б. Юр'єва ${ }^{1}$, Т. П. Осолодченко \\ Національний фрармацевтичний університет МОЗ України ${ }^{1}$ \\ ДУ «Інститут мікробіології та імунології імені І. І. Мечникова» АМН України ${ }^{2}$ \\ yurieva.anyuta@gmail.com
}

ІНФОРМАЦІЯ

Надійшла до редакції / Received: 28.01.2021

Після доопрацювання / Revised: 10.02.2021

Прийнято до друку / Accepted: 12.02.2021

\section{Ключові слова:}

суспензія;

антибактеріальна активність; методи дослідження.

\begin{abstract}
АНОТАЦІЯ
Мета роботи. Дослідження антибактеріальних властивостей екстемпоральної суспензії з вісмуту нітратом основним для подальшого створення лікарського засобу для застосування в гастроентерології, зокрема терапії пептичних виразок шлунка та дванадцятипалої кишки.

Матеріали і методи. Об'єкти дослідження: зразки суспензії з вісмуту нітратом основним виготовлені за традиційною технологією (прийом скаламучення) та із додаванням стабілізатора. Для дослідження антибактеріальних властивостей використали еталонні тест-культури грампозитивних і грамнегативних бактерій, які належать до різних таксономічних груп, зокрема Staphylococcus aureus ATCC 25923, Escherichia coli ATCC 25922, Pseudomonas aeruginosa ATCC 27853, Bacillus subtilis ATCC6633, Proteus vulgaris ATCC 4636. Протигрибкову дію зразків досліджено на референтному штамі Candida albicans ATCC 885-653.

Результати й обговорення. Результати проведених досліджень свідчать, що зразок із вмістом допоміжних речовин виявляє більш виражену антимікробну дію до всіх досліджуваних штамів мікроорганізмів, про що свідчить значення діаметра зон затримки росту та часу експозиції порівняно зі зразком, виготовленим за традиційною технологією.

Висновки. Доведено антибактеріальну активність зразків екстемпоральної суспензії відносно еталонних тест-культур грампозитивних і грамнегативних бактерій. Встановлено, що вміст допоміжних речовин у складі суспензії не знижує антибактеріальну активність зразка суспензії, а навіть підвищує ії майже для всіх штамів мікроорганізмів.
\end{abstract}

Вступ. Виразкова хвороба (пептична виразка) хронічне рецидивуюче поліциклічне захворювання слизової оболонки гастродуоденальної зони з фрормуванням локального ерозивного ушкодження хелікобактерного або інфекційного походження з порушеннями балансу між фракторами «агресії» та «захисту». Захворювання діагностують у 7-10 \% дорослого населення.

У розвитку пептичної виразки шлунку суттєве значення має хелікобактерне ураження слизової обо- лонки шлунка. В Україні та країнах Східної Європи 9 із 10 пептичних виразок зумовлені H. pylori.

H. pylori - грамнегативна спіралеподібна бактерія, яка живе на поверхні слизової оболонки шлунка людини, вона стійка до бактерицидного впливу соляної кислоти в його порожнині. Ця інфрекція в 60-80 \% випадків є причиною розвитку пептичної виразки шлунка та дванадцятипалої кишки[1-3].

ISSN 2312-0967. Pharmaceutical review. 2021. № 1 
Фармацевтична технологія, біофармація, гомеопатія Pharmaceutical technology, biopharmacy, homeopathy

Серед засобів, які пригнічують хелікобактерну інфекцію, перспективними $€$ препарати вісмуту, які проявляють ефективність навіть у хворих із резистентними до антибіотиків штамами H. pylori [4-7].

При пероральному застосуванні лікарських засобів, які містять солі вісмуту, зокрема у формі суспензій, гелів, таблеток, на поверхні слизової оболонки шлунково-кишкового тракту утворюється захисна плівка - хелатні з'єднання з білковим субстратом. Ця плівка сприяє загоєнню пептичних виразок та зменшенню прояву місцевого запального процесу. Препарати вісмуту виявляють антибактеріальну дію, зокрема пригнічують ріст бактерій Н. pylori [8-10].

Потрібно зауважити, що більшість із них представлені у вигляді твердих лікарських фрорм, а саме таблеток та капсул, що мають меншу біодоступність порівняно з рідкими лікарськими формами, зокрема, розчинами, суспензіями, емульсіями. До недоліків цих препаратів можна також віднести високу вартість та розвиток побічних дій при тривалому застосуванні $[11,12]$.

У сучасному арсеналі вісмутовмісних препаратів відсутні лікарські засоби у вигляді рідких лікарських форм, зокрема оральної суспензії. Проте відомо, що суспензії дають можливість підвищити терапевтичну дію активного фрармацевтичного інгредієнта та забезпечують зручне вживання лікарського засобу [13, 14]. Створення лікарського засобу для комплексного лікування хелікобактер-асоційованої пептичної виразки шлунка та дванадцятипалої кишки є першочерговим завданням сучасної фрармації та медицини.

Мета роботи - дослідження антибактеріальних властивостей екстемпоральної суспензії з вісмуту нітратом основним для подальшого створення лікарського засобу для застосування у гастроентерології.

Матеріали і методи. Дослідження антибактеріальних властивостей суспензії з вісмуту нітратом основним проводили для зразків суспензій, виготовлених за традиційною технологією (зразок 1 - без додавання допоміжних речовин) та із додаванням стабілізатору (зразок 2).

Для дослідження антибактеріальних властивостей зразків суспензій використано еталонні тест-культури грампозитивних і грамнегативних бактерій, які належать до різних таксономічних груп, зокрема Staphylococcus aureus ATCC 25923, Escherichia coli ATCC 25922, Pseudomonas aeruginosa ATCC 27853, Bacillus subtilis ATCC6633, Proteus vulgaris ATCC 4636. Протигрибкову дію зразків досліджено на рефрерентному штамі Candida albicans ATCC 885-653. Зазначений набір тест-штамів є загальноприйнятий при первинному визначенні протимікробної дії. Усі тест-культури одержано з лабораторії медичної мікробіології з Музеєм мікроорганізмів ДУ "ІМІ ім. І. І. Мечникова НАМН України". Середовища для культивування застосовували відповідно до виду мікроорганізмів згідно з існуючими методичними розробками і рекомендаціями $[15,16]$.
Приготування суспензій мікроорганізмів із визначеною концентрацією мікробних клітин (оптична щільність) проводили за допомогою стандарту каламутності (0,5 од. за шкалою McFarland). Використовували прилад Densi-La-Meter (виробництва PLIVALachema, Чехія; довжина хвилі 540 нм). Суспензію готували згідно з інструкцією до приладу та інформаційного листа про нововведення в системі охорони здоров'я № 163-2006 «Стандартизація приготування мікробних суспензій», м. Київ. Синхронізацію культур проводили за допомогою низької температури $\left(4^{\circ} \mathrm{C}\right)$.

Визначення чутливості штамів мікроорганізмів до досліджуваних зразків проводили відповідно до методичних вказівок «Визначення чутливості мікроорганізмів до антибактеріальних препаратів» (наказ Міністерства охорони здоров'я України від 05.04.2007 р. № 167) методом колодязів на середовищі МюллераХинтона (HIMediaLaboratorlesPvt. LtdIndia). Середовище готували відповідно до інструкції виробника. Чутливість грибів визначали на середовищі Сабуродекстрозний агар.

Визначення чутливості дослідних зразків виконували на двох шарах поживного середовища, які розливали у чашки Петрі. Нижній шар складався 3 агарагару (10 мл). На нього встановлювали 3-6 металеві стерильні циліндри діаметром 8 мм та висотою 10 мм. Навколо циліндрів заливали верхній шар (14 мл поживного середовища + 1 мл мікробного розчину 0,5 од. за шкалою McFarland), який складався 3 поживного агаризованого середовища з відповідним стандартом добової культури мікроорганізму. Після застигання стерильним пінцетом виймали колодязі і в лунки вносили дослідну речовину (0,3 мл).

Оцінку антибактеріальної активності дослідних зразків проводили за діаметром зон затримки росту:

10 мм - мікроорганізм не чутливий до дослідного зразка;

10-15 мм - мікроорганізм слабочутливий до дослідного зразка;

15-25 мм - мікроорганізм чутливий до дослідного зразка;

25 мм та вище - мікроорганізм високочутливий до дослідного зразка.

Мікробіологічні дослідження в умовах in vitro проводили в ДУ «IMIHАМН» під керівництвом завідувача лабораторії біохімії мікроорганізмів і поживних середовищ Т. П. Осолодченко.

Результати й обговорення. Результати проведених дослідження свідчать, що зразок 2 виявляє більш виражену антимікробну дію до всіх досліджуваних штамів мікроорганізмів порівняно зі зразком 1. Комбінація активного фрармацевтичного інгредієнта в досліджуваному зразку 2 з вмістом допоміжних речовин підвищує антимікробну дію вісмуту нітрату основного до наведених штамів мікроорганізмів, про що свідчать максимальні значення діаметра зон затримки росту (табл. 1).

ISSN 2312-0967. Фармацевтичний часопис. 2021. № 1 
Фармацевтична технологія, біофармація, гомеопатія Pharmaceutical technology, biopharmacy, homeopathy

Таблиця 1

Антибактеріальна активність зразків суспензії

\begin{tabular}{|c|c|c|c|c|c|c|}
\hline \multirow[b]{3}{*}{ Зразки } & \multicolumn{6}{|c|}{ Діаметри зон затримки росту, мм } \\
\hline & \multicolumn{6}{|c|}{ Музейні штами } \\
\hline & $\begin{array}{c}\text { Staphylococcus } \\
\text { aureus } \\
\text { ATCC } 25923\end{array}$ & $\begin{array}{c}\text { Escherichia } \\
\text { coli ATCC } \\
25922\end{array}$ & $\begin{array}{c}\text { Proteus } \\
\text { vulgaris ATCC } \\
4636\end{array}$ & $\begin{array}{c}\text { Pseudomonas } \\
\text { aeruginosa } \\
\text { ATCC } 27853\end{array}$ & $\begin{array}{c}\text { Basillus } \\
\text { subtilis } \\
\text { ATCC } 6633\end{array}$ & $\begin{array}{c}\text { Candida } \\
\text { albicans ATCC } \\
653 / 885\end{array}$ \\
\hline Зразок 1 & $20,7 \pm 0,4$ & $17,3 \pm 0,3$ & ріст & ріст & $20,0 \pm 0,2$ & $15,7 \pm 0,3$ \\
\hline Зразок 2 & $21,3 \pm 0,2$ & $18,7 \pm 0,2$ & ріст & $17,7 \pm 0,3$ & $21,7 \pm 0,3$ & $16,5 \pm 0,2$ \\
\hline \multicolumn{7}{|c|}{ Клінічні штами } \\
\hline \multirow[b]{2}{*}{ Зразок 1} & $\begin{array}{c}\text { Staphylococcus } \\
\text { aureus }\end{array}$ & $\begin{array}{c}\text { Escherichia } \\
\text { coli }\end{array}$ & $\begin{array}{c}\text { Klebsiella } \\
\text { pneumoniae }\end{array}$ & $\begin{array}{c}\text { Pseudomonas } \\
\text { aeruginosa }\end{array}$ & $\begin{array}{c}\text { Campylobacter } \\
\text { spp. }\end{array}$ & $\begin{array}{l}\text { Candida } \\
\text { albicans }\end{array}$ \\
\hline & $18,3 \pm 0,3$ & $16,0 \pm 0,2$ & ріст & $15,2 \pm 0,3$ & $17,7 \pm 0,4$ & $13,3 \pm 0,4$ \\
\hline Зразок 2 & $20,3 \pm 0,4$ & $17,7 \pm 0,3$ & ріст & $16,3 \pm 0,2$ & $19,3 \pm 0,4$ & $15,0 \pm 0,2$ \\
\hline
\end{tabular}

Примітка: $\mathrm{n=5;} P=95 \%$.

При знезаражені модельних тест-об'єктів, що імітують слизові оболонки людини штучно контамінованих тест-мікроорганізмами, визначали кількість мікроорганізмів на твердому середовищі при розведенні зразків
(1:1) та у чистому вигляді при експозиції 10 хв, 20 хв, 30 хв, 60 хв, 90 хв, 120 хв, 180 хв, 24 год та 48 год після контакту дослідного зразка з тест-мікроорганізмами. Результати досліджень наведено в таблиці 2.

Таблиця 2

Визначення бактерицидної активності зразків суспензії з вісмуту нітратом основним

\begin{tabular}{|c|c|c|c|c|c|c|c|c|c|}
\hline \multirow{2}{*}{$\begin{array}{c}\text { Зразок/ } \\
\text { розведення }\end{array}$} & \multicolumn{9}{|c|}{ Експозиція (хв)/мікроорганізм } \\
\hline & 10 & 20 & 30 & 60 & 90 & 120 & 180 & 24 год & 48 год \\
\hline 1 & 2 & 3 & 4 & 5 & 6 & 7 & 8 & 9 & 10 \\
\hline \multicolumn{10}{|c|}{ Staphylococcus aureus ATCC 25922} \\
\hline \multicolumn{10}{|l|}{ Зразок 1} \\
\hline Цілий & + & + & + & - & - & - & - & - & + \\
\hline 1:1 & + & + & + & - & - & - & - & + & + \\
\hline \multicolumn{10}{|l|}{ Зразок 2} \\
\hline Цілий & + & + & - & - & - & - & - & - & + \\
\hline 1:1 & + & + & - & - & - & - & - & - & + \\
\hline \multicolumn{10}{|c|}{ Escherichia coli ATCC 25922} \\
\hline \multicolumn{10}{|l|}{ Зразок 1} \\
\hline Цілий & + & + & + & - & - & - & - & - & + \\
\hline 1:1 & + & + & + & + & - & - & - & + & + \\
\hline \multicolumn{10}{|l|}{ Зразок 2} \\
\hline Цілий & + & + & - & - & - & - & - & - & + \\
\hline 1:1 & + & + & - & - & - & - & - & - & + \\
\hline \multicolumn{10}{|c|}{ Proteus vulgaris ATCC 4636} \\
\hline \multicolumn{10}{|l|}{ Зразок 1} \\
\hline Цілий & + & + & + & - & - & - & - & + & + \\
\hline $1: 1$ & + & + & + & + & + & + & + & + & + \\
\hline
\end{tabular}

ISSN 2312-0967. Pharmaceutical review. 2021. № 1 
Фармацевтична технологія, біофармація, гомеопатія Pharmaceutical technology, biopharmacy, homeopathy

Продовження табл. 2

\begin{tabular}{|c|c|c|c|c|c|c|c|c|c|}
\hline 1 & 2 & 3 & 4 & 5 & 6 & 7 & 8 & 9 & 10 \\
\hline \multicolumn{10}{|l|}{ Зразок 2} \\
\hline Цілий & + & + & - & - & - & - & - & - & + \\
\hline $1: 1$ & + & + & + & + & + & + & + & + & + \\
\hline \multicolumn{10}{|c|}{ Pseudomonas aeruginosa ATCC 27853} \\
\hline \multicolumn{10}{|l|}{ Зразок 1} \\
\hline Цілий & + & + & + & - & - & - & - & + & + \\
\hline $1: 1$ & + & + & + & + & + & + & + & + & + \\
\hline \multicolumn{10}{|l|}{ Зразок 2} \\
\hline Цілий & + & + & - & - & - & - & - & - & + \\
\hline $1: 1$ & + & + & + & + & + & + & + & + & + \\
\hline \multicolumn{10}{|c|}{ Basillus subtilis ATCC 6633} \\
\hline \multicolumn{10}{|l|}{ Зразок 1} \\
\hline Цілий & + & + & + & - & - & - & - & - & + \\
\hline $1: 1$ & + & + & + & + & - & - & - & + & + \\
\hline \multicolumn{10}{|l|}{ Зразок 2} \\
\hline Цілий & + & + & - & - & - & - & - & - & + \\
\hline $1: 1$ & + & + & - & - & - & - & - & - & + \\
\hline \multicolumn{10}{|c|}{ Candida albicans ATCC 653/88 } \\
\hline \multicolumn{10}{|l|}{ Зразок 1} \\
\hline Цілий & + & + & + & - & - & - & - & - & + \\
\hline 1:1 & + & + & + & - & - & - & - & - & + \\
\hline \multicolumn{10}{|l|}{ Зразок 2} \\
\hline Цілий & + & + & - & - & - & - & - & - & + \\
\hline $1: 1$ & + & + & - & - & - & - & - & - & + \\
\hline
\end{tabular}

Примітки: «+»- ріст мікроорганізмів , «-»- немає росту.

За даними результатів дослідження, зразок 2 проявляв бактерицидну дію після експозиції 30 хв відносно всіх штамів мікроорганізмів, а для зразка 1 цей показник становив 60 хв. Отже, за швидкістю прояву бактерицидної дії кращі результати спостерігали для зразка суспензії із вмістом допоміжних речовин.

Для визначення кількісного складу мікроорганізмів після взаємодії із зразками суспензії проведено дослід, в якому до складу поживного середовища додавали відповідну кількість зразку 1 та 2, а після засівання мікроорганізмами (кількість складала $10^{2}$ мікробних клітин на мл) проводили облік кількості колоній, що виросли порівняно 3 контролем. Результати наведено в таблиці 3.

За даними результатів дослідження, кількісний показник відрізнявся для зразка 2 відносно Staphylococcus aureus ATCC 25923, Escherichia coli ATCC 25922,

Таблиця 3

Визначення кількісного складу колоній мікроорганізмів (КУО) після взаємодії з досліджуваними зразками суспензії

\begin{tabular}{|l|c|c|c|c|c|c|}
\hline \multirow{2}{*}{ Зразок } & \multicolumn{7}{|c|}{\begin{tabular}{c} 
КУО/Мл \\
\cline { 2 - 8 } \\
ATCC 25923
\end{tabular}} & $\begin{array}{c}\text { Staphlococcus } \\
\text { aureus } \\
\text { coli ATCC }\end{array}$ & $\begin{array}{c}\text { Escherichia } \\
\text { AT922 }\end{array}$ & $\begin{array}{c}\text { Proteus } \\
\text { vulgaris ATCC } \\
\mathbf{4 6 3 6}\end{array}$ & $\begin{array}{c}\text { Pseudomonas } \\
\text { aeruginosa } \\
\text { ATCC 27853 }\end{array}$ & $\begin{array}{c}\text { Basillus } \\
\text { subtilis } \\
\text { ATCC 6633 }\end{array}$ & $\begin{array}{c}\text { Candida } \\
\text { albicans } \\
\text { ATCC 653/885 }\end{array}$ \\
\hline Зразок 1 & $10^{4}$ & $10^{5}$ & $10^{5}$ & $10^{5}$ & $10^{4}$ & $10^{4}$ \\
\hline Зразок 2 & $10^{3}$ & $10^{4}$ & $10^{5}$ & $10^{4}$ & $10^{4}$ & $10^{4}$ \\
\hline Контроль & $10^{5}$ & $10^{5}$ & $10^{5}$ & $10^{5}$ & $10^{5}$ & $10^{5}$ \\
\hline
\end{tabular}

ISSN 2312-0967. Фармацевтичний часопис. 2021. № 1 
Pseudomonas aeruginosa ATCC 27853, BacilIus subtilis ATCC6633, Candida albicans ATCC 885-653. Y випадку Proteus vulgaris ATCC 4636 кількісних змін не спостерігали для обох зразків порівняно з контролем.

Висновки. 1. Доведено антибактеріальну активність зразків екстемпоральної суспензії відносно еталонних тест-культур грампозитивних і грамнегативних бактерій.
Фармацевтична технологія, біофармація, гомеопатія Pharmaceutical technology, biopharmacy, homeopathy

2. Встановлено, що вміст допоміжних речовин у складі суспензії не знижує антибактеріальну активність зразка суспензії, а навіть підвищує її майже для всіх штамів мікроорганізмів.

Конфлікт інтересів: відсутній.

Conflicts of interest: authors have no conflict of interest to declare.

\title{
RESEARCH OF ANTIBACTERIAL PROPERTIES OF EXTEMPORANEOUS SUSPENSION WITH BISMUTH NITRATE BASIC
}

\author{
G. M. Melnyk' ${ }^{1}$, T. H. Yarnykh ${ }^{1}$, G. B. Yuryeva ${ }^{1}$ T. P. Osolodchenko ${ }^{2}$
}

National University of Pharmacy ${ }^{1}$, Kharkiv

I. Mechnykov Institute of Microbiology and Immunology, National Academy of Medical Sciences of Ukraine ${ }^{2}$

yurieva.anyuta@gmail.com

The aim of the work. Research of the antibacterial properties of the extemporaneous suspension with bismuth nitrate basic for the further development of a drug for use in gastroenterology, in particular the treatment of peptic ulcers of the stomach and duodenum.

Materials and Methods. Samples of basic bismuth nitrate suspension, mainly made by traditional technology (method of "making muddy") and with the adding of a stabilizers were the objects of the examination. For the study of antibacterial properties there were used reference test cultures of gram-positive and gram-negative bacteria belonging to different taxonomic groups, in particular Staphylococcus aureus ATCC 25923, Escherichia coli ATCC 25922, Pseudomonas aeruginosa ATCC 27853, Bacillus subtilis ATCC6633, Proteus vulgaris ATCC 4636. The antifungal effect of the samples was investigated on the reference strain of Candida albicans ATCC 885-653.

Results and Discussion. The results of the study show that the sample with the content of excipients has a more pronounced antimicrobial effect on all the studied strains of microorganisms, as evidenced by the values of the diameter of the growth inhibition zones and the exposure time in comparison with the sample prepared according to the traditional technology.

Conclusions. The antibacterial activity of extemporaneous suspension samples against reference test cultures of grampositive and gram-negative bacteria was established. It was found that the content of excipients in the suspension does not reduce the antibacterial activity of the suspension sample, but also increases it for almost all strains of microorganisms.

Key words: suspension; antibacterial activity; research methods.

\section{ИССЛЕДОВАНИЕ АНТИБАКТЕРИАЛЬНЫХ СВОЙСТВ ЭКСТЕМПОРАЛЬНОЙ СУСПЕНЗИИ С ВИСМУТОМ НИТРАТОМ ОСНОВНЫМ}

\author{
Г. Н. Мельник ${ }^{1}$, Т. Г. Ярных ${ }^{1}$, А. Б. Юрьева ${ }^{1}$, Т. П. Осолодченко ${ }^{2}$ \\ Национальный фрармацевтический университет Мз Украины ${ }^{1}$ \\ ГУ «Институт микробиологии и иммунологии имени И. И. Мечникова» АМН Украинь ${ }^{2}$ \\ yurieva.anyuta@gmail.com
}

Цель роботы. Исследование антибактериальных свойств экстемпоральной суспензии с висмутом нитратом основным для дальнейшего создания лекарственного средства для применения в гастроэнтерологии, в частности терапии пептических язв желудка и двенадцатиперстной кишки.

Материалы и методы. Объекты исследования: образцы суспензии с висмутом нитратом основным, изготовленные по традиционной технологии (прием взмучивания) исдобавлением стабилизатора. Для исследования антибактериальных свойств были использованы эталонные тест-культуры граммположительных и граммотрицательных бактерий, принадлежащих к различным таксономическим группам, в частности Staphylococcus aureus ATCC 25923, Escherichia coli ATCC 25922, Pseudomonas aeruginosa ATCC 27853, Bacillus subtilis ATCC6633, Proteus vulgaris ATCC 4636. Противогрибковое действие образцов исследовано на референтном штамме Candida albicans ATCC 885-653.

Результаты и обсуждение. Результаты проведенных исследований показывают, что образец с содержанием вспомогательных веществ оказывает более выраженное антимикробное действие ко всем исследуемым штаммам

ISSN 2312-0967. Pharmaceutical review. 2021. № 1 
Фармацевтична технологія, біофармація, гомеопатія

Pharmaceutical technology, biopharmacy, homeopathy

микроорганизмов, о чем свидетельствует значение диаметра зон задержки роста и время экспозиции в сравнении с образцом, приготовленным согласно традиционной технологии.

Выводы. Доказана антибактериальная активность образцов экстемпоральной суспензии по отношению к эталонным тест-культурам граммположительных и граммотрицательных бактерий. Установлено, что содержание вспомогательных веществ в составе суспензии не снижает антибактериальную активность образца суспензии, а даже повышает ее почти для всех штаммов микроорганизмов.

Ключевые слова: суспензия; антибактериальная активность; методы исследования.

\section{Список бібліографрічних посилань}

1. Helicobacter pylori impedes acid-induced tightening of gastric epithelial junctions. E. A. Marcus, O. Vagin, E. Tokhtaeva et al. Am. J. Physiol. Gastrointest. Liver Physiol. 2013. No. 305, P 731-739. DOI: 10.1152/ajpgi.00209.2013

2. Хіміон Л. В., Ященко О. Б., Данилюк С. В., Ситюк Т. О. Сучасні підходи до діагностики та ведення хворих на виразкову хворобу шлунка та дванадцятипалої кишки на первинному рівні медичної допомоги. Семейная медицина. 2018. № 1(75). С. 6-11.

3. Хвороби органів травлення (діагностика і лікування) : навч. посіб. 2-ге вид. / Григор'єв П. Я. та ін. Тернопіль : Укрмедкнига, 2012. 448 с.

4. Treatment of Helicobacter pylori infection 2016 A. O'Connor, W. Fischbach, J. P. Gisbert, C. O'Morain. Helicobacter. 2016. Vol. 1. P. 55-61.

5. Kyoto global consensus report on Helicobacter pylori gastritis. K. Sugano, J. Tack, E. J. Kuipers et al. Gut. 2015. Vol. 64. P. 1353-1367.

6. Angel Lanas, Francis K. L. Chan peptic ulcer disease. The Lancet. 2017. Vol. 10094. P. 613-624.

7. European Helicobacter and Microbiota Study Group and Consensus panel. Management of Helicobacter pylori infection - the Maastricht V. Florence Consensus Report. P. Malfertheiner, F. Mégraud, C. O'Morain et al. Gut. 2017 Vol. 66 (1). P. 6-30. DOI: 10.1136/ gutjnl-2016-312288.

8. Mendis A. H. W., Marshall B. J. Biological chemistry of arsenic, antimony and bismuth. Sun $\mathrm{H}$ (Ed.). Singapore: John Wiley \& Sons Ltd., 2011. 400 p.

9. Tracking Bismuth anti-ulcer drug uptake in single Helicobacter pylori cells. C. N. Tsang, K. S. Ho, H. Sun, W. T. Chan. J. Am. Chem. Soc. 2011. Vol. 133, No. 19. P. 7355-7357.

10. Xia W., Li H., Sun H. Functional disruption of HypB, a GTPase of Helicobacter pylori, by bismuth. Chem Commun (Camb). 2014. Vol. 50, No. 13. P. 1611-1614.

11. Державний реєстр лікарських засобів України. URL: http://www.drlz.kiev.ua

12. Довідник «Компендіум». URL: http://compendium. com.ua

13. Pharmacopoeian aspects of suspensions preparation in pharmacy conditions. T. G. Yarnykh, O. I. Tykhonov, G. M. Melnyk, G. B. Yuryeva. Asian Journal of Pharmaceutics. 2017. Vol. 11 (4). P. 859-864.

14. Екстемпоральна рецептура (технологія, аналіз, застосування) : метод. реком. / під ред. О. І. Тихонова і Т. Г. Ярних / Тихонов О. та ін. Київ : Видавничий дім «Агентство Медичного Маркетингу», 2016. 352 с.

15. Вивчення специфічної активності протимікробних лікарських засобів : метод. реком. / за ред. Ю. Л. Волянського. Київ, 2004. 38 с.

16. Державна Фармакопея України : в 3-х т. / ДП «Український науковий фрармакопейний центр якості лікарських засобів». 2-е вид. Харків : ДП «Український науковий фрармакопейний центр якості лікарських засобів», 2014. Т. 3. 732 с.

\section{References}

1. Marcus EA, Vagin O, Tokhtaeva E, Sachs G, Scott DR. Helicobacter pylori impedes acid-induced tightening of gastric epithelial junctions. Am J Physiol Gastrointest. Liver Physiol. 2013;305: 731-9. DOI: 10.1152/ajpgi.00209.2013

2. Himion LV, Yashchenko OB, Danilyuk SV, Sityuk TO. [Modern approaches to the diagnosis and management of patients with peptic ulcer of the stomach and duodenum at the primary level of care]. Semeynaya meditsina. 2018;1(75): 6-11. Ukrainian.

3. Grigorev P Ya, Starodub EM, Yakovenko EP. Diseases of the digestive system (diagnosis and treatment): textbook. [Хвороби органів травлення (діагностика і лікування): навч. посіб.] Ternopil: Ukrmedknyha; 2012. Ukrainian.

4. O'Connor A, Fischbach W, Gisbert JP, O'Morain C. Treatment of Helicobacter pylori infection. Helico-

bacter. 2016;1: 55-61.

5. Sugano K, Tack J, Kuipers EJ. Kyoto global consensus report on Helicobacter pylori gastritis. Gut. 2015;64: 1353-67.

6. Angel Lanas, Francis KL. Chan peptic ulcer disease. The Lancet. 2017;10094: 613-24.

7. Malfertheiner P, Mégraud F, O'Morain C. European Helicobacter and Microbiota Study Group and Consensus panel. Management of Helicobacter pylori infection - the Maastricht V/Florence Consensus Report. Gut. 2017;66(1): 6-30. DOI: 10.1136/ gutjnl-2016-312288

8. Mendis AHW, Marshall BJ. Helicobacter pylori and bismuth / Biological chemistry of arsenic, antimony and bismuth. Sun H (Ed.). Singapore: John Wiley \& Sons Ltd., 2011.

9. Tsang CN, Ho KS, Sun H, Chan WT. Tracking Bismuth anti-ulcer drug uptake in single Helicobacter pylori

ISSN 2312-0967. Фармацевтичний часопис. 2021. № 1 
Фармацевтична технологія, біофармація, гомеопатія Pharmaceutical technology, biopharmacy, homeopathy

cells. J Am Chem Soc. 2011;133(19): 7355-7.

10. Xia W, Li H, Sun H. Functional disruption of HypB, a GTPase of Helicobacter pylori, by bismuth. Chem Commun (Camb). 2014;50(13): 1611-4.

11. State Register of Medicines of Ukraine. [Державний реєстр лікарських засобів України] Available from: http://www.drlz.kiev.ua/ Ukrainian.

12. Compendium Directory [Internet]. Available from: http:// compendium.com.ua.

13. Yarnykh TG, Tykhonov OI, Melnyk GM, Yuryeva GB. Pharmacopoeian aspects of suspensions preparation in pharmacy conditions. Asian Journal of Pharmaceutics. 2017;11(4): 859-64.
14. Tykhonov OI, Yarnykh TH, Hrytsenko IS, Khokhlenkova NV. Extemporal Formulation (Technology, Analysis, Application): Methodical recommendations. [Екстемпоральна рецептура (технологія, аналіз, застосування): метод. реком.] Kyiv: Publishing House Agency of Medical Marketing; 2016. Ukrainian.

15. Voliansky YL, Gritsenko IS, Shirobokov VP et al. The study of the specific activity of antimicrobial drugs: Method. Recom. Kiev. 2004. 38 p. Ukrainian.

16. State Pharmacopoeia of Ukraine: in 3 volumes. [Державна Фармакопея України: в 3-х т.] Kharkiv: DP "Ukrainskyi naukovyi farmakopeinyi tsentr yakosti likarskykh zasobiv". Ukrainian.

\section{Відомості про авторів}

Мельник Г. М. - канд. фрармац. наук, докторантка кафредри технології ліків, Національний фрармацевтичний університет МО3 України, Харків. E-mail: tI@nuph.edu.ua, ORCID 0000-0002-4333-2094.

Ярних Т. Г. - д. фрармац. наук, профресор, завідувачка кафедри технології ліків, Національний фрармацевтичний університет МО3 України, Харків. E-mail: tl@nuph.edu.ua, ORCID 0000-0001-8496-1578.

Юр'єва Г. Б. - канд. фрармац. наук, доцентка кафедри технології ліків, Національний фрармацевтичний університет MO3 України, Харків. E-mail: yurieva.anyuta@gmail.com, ORCID 0000-0001-9719-2122.

Осолодченко Т. П. - канд. біол. наук, завідувачка лабораторії біохімії мікроорганізмів та живильних середовищ, ДУ «Інститут мікробіології та імунології імені I. І. Мечникова» AMH України, Харків. E-mail: imi lbb@ukr.net, ORCID 0000-0001-7258-3880.

\section{Information about the authors}

Melnyk G. M. - PhD (Pharmacy), postdoctoral student of the Technology of Drugs Department, National University of Pharmacy of the Ministry of Health of Ukraine, Kharkiv. E-mail: tl@nuph.edu.ua, ORCID 0000-0002-4333-2094.

Yarnykh T. H. - DSc (Pharmacy), Professor, Head of the Technology of Drugs Department, National University of Pharmacy of the Ministry of Health of Ukraine, Kharkiv. E-mail: tl@nuph.edu.ua, ORCID 0000-0001-8496-1578.

Yuryeva G. B. - PhD (Pharmacy), Associate Professor of the Technology of Drugs Department, National University of Pharmacy of the Ministry of Health of Ukraine, Kharkiv. E-mail: yurieva.anyuta@gmail.com, ORCID 0000-0001-9719-2122. Osolodchenko T. P. - PhD (Biology), Head of the Laboratory of Biochemistry of Microorganisms and Nutrient Medium, I. Mechnykov Institute of Microbiology and Immunology, National Academy of Medical Sciences of Ukraine, Kharkiv. E-mail: imi_lbb@ukr.net, ORCID 0000-0001-7258-3880. 